[Agr. Biol. Chem., Vol. 31, No. 1, p. 92 100, 1967]

\title{
Studies on the Nucleases Produced by Microorganisms
}

\author{
Part III. Properties of Partially Purified Phosphodiesterase \\ (5'-Nucleotide-Forming) Produced by Pellicularia $\mathrm{sp}^{*, * *}$
}

\author{
By Yushin Fujnura, Yasuhiro Hasegawa, Yasuyuki Kaneko \\ and Shinji Dor \\ Department of Agricultural Chemistry, College of Agriculture, \\ Nagoya University, Chikusa-Ku, Nagoya-City \\ Received August 11, 1966
}

\begin{abstract}
The properties of crude phosphodiesterase forming $5^{\prime}$-mononucleotide of Pellicularia $\mathrm{H}-11$ were investigated on its metal requirement, $\mathrm{pH}$ response for activity and so on. The dialyzate of crude PDase against distilled water became partly inactive, but was recovered with $\mathrm{Zn}^{++}, \mathrm{Mn}^{++}$and $\mathrm{Mg}^{++}$, whereas completely inactivated dialyzate against EDTA was restored specifically with only $\mathrm{Zn}^{++}$

The optimum pH of PDase activity was 5.0 and that of ribonuclease 4.0 . The crude PDase was partially purified by acetone fractionation and Amberlite IRG-50 (XE-64) or CM-cellulose column chromatography. Two PDase and a RNase activities were recognized.

Pellicularia PDase was found to be of new type according to its $\mathrm{Zn}++$ dependency and non-activity towards bis- $p$-nitrophenyl phosphate.
\end{abstract}

\section{INTRODUCTION}

Certain nucleases of different specificities are used for determination of nucleotide arrangements in nucleic acids. (Pancreatic RNase: EG 2.7.7.16, RNase $\mathrm{T}_{1}$ : EG 3.1.4.8, snake venom PDase.) And there have been found several nucleases having different properties or specificities in many organisms. Many of them are those hydrolyzing RNA or DNA to 3'-mononucleotides or oligonucleotides having $3^{\prime}$-terminal phosphate. ${ }^{1 \sim 10)} \mathrm{Be}$ -

* The report was presented at the Central District Branch Meeting of the Agricultural Chemical Society of Japan, Nagoya, March 25, 1963, and also at the Central District Branch Meeting of the Biochemical Society of Japan, Nagoya, December 14, 1963.

** The following abbreviations are used: PDase, phosphodiesterase; RNase, ribonuclease; bis-p-NPP, bis-p-nitrophenyl phosphate.

1) S. Nishimura, Biochim. Biophys. Acta, 45, 15 (1960).

2) M. Kerr, E. A. Pratland and I. R. Lehman, Biochim. Biophys. Res. Comm., 20, 154 (1965).

$3)$ K. Sato-Asano, J. Biochem., 46, 31 (1959). sides, nucleases hydrolyzing RNA or DNA to 5 '-mononucleotides or oligonucleotides having 5 -terminal phosphate have been found in $E$. coli, ${ }^{11-13 !}$ Azotobacter agilis, ${ }^{14,15 !}$ Penicillium, ${ }^{26)}$

4) M. Naoi-Tada, K. Sato-Asano and F. Egami, J. Biochem., 46, 757 (1959).

5) W. Fiers and H. G. Khorana, J. Biol. Chem. 238, 2780 (1963).

6) W. Fiers and H. G. Khorana, ibid., 238, 2789 (1963).

7) D. G. Glitz and C. A. Dekker, Biochemistry, 3, 1391 (1964).

8) D. G. Glitz and C. A. Dekker, ibid., 3, 1399 (1964)

9) S. Linn and I. R. Lehman, J. Biol. Chem., 240, $1287(1965)$.

10) S. Linn and I. R. Lehman ibid., 240, 1294 (1965)

11) I. R. Lehman and A. L. Nussbaum, ibid., 239 2628 (1964).

12) C. C. Richardson and A. Kornberg, ibid., 239 242 (1964).

13) C. C. Richardson, I. R. Lehman and A. Kornberg, ibid., 239, 251 (1964).

14) A. Steavens and R. J. Hilmoe, ibid., 235, 3016 (1960).

15) A. Steavens and R.J. Hilmoe, ibid., 235, 3023 (1960). 


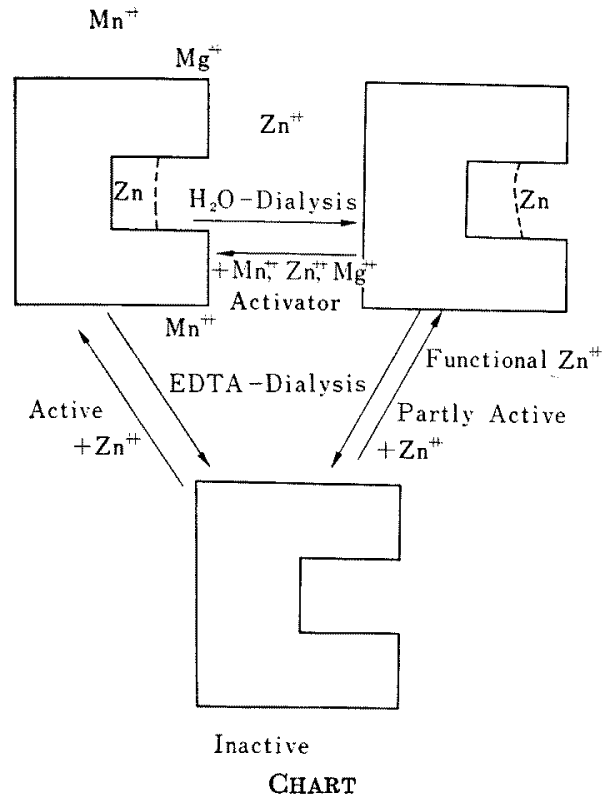

Asterococcus, ${ }^{171}$ Rhodotorula ${ }^{181}$ and so on.

It does not need many words to mention that the PDase-producing microorganism, which can be cultivated in a large scale, is useful for fermentation industry, because $5^{\prime}$ IMP and 5'-GMP are good seasoning for Japanese food.

A new type of nuclease would contribute to investigation of a primary structure in nucleic acids. The screening of microorganism producing activity of PDase as high as possible has been carried out already in the previous reports, using about three hundred strains of Phycomycetes, Ascomycetes, Basidiomycetes and Fungi Imperfecti. PDase activity of Pellicularia $\mathrm{H}-11$ strain was the highest.

The procedures in cultivation and some properties of this PDase were also previously

16) A. Kuninaka, S. Otsuka, K. Kobayashi and Sakaguchi, Bull. Agr. Chem. Soc. Japan,, 23, 239 (1959).

17) P. Plakett, Biochim. Biophys. Acta, 26, 664 (1957).

18) Y. Nakao and K. Ogata, This Journal, 27, 499 (1963). reported. ${ }^{19,201}$ This paper describes some properties and substrate specificities of crude and partially purified PDases.

The enzyme was found to be of new type because of its $\mathrm{Zn}^{++}$dependency and nonactivity towards bis- $p$-NPP.

\section{MATERIALS AND METHODS}

Strain and Culture Medium. Pellicularia $\mathrm{H}-\mathrm{ll}$ and the following medium were used: glucose $5 \%$, Mikuni meat extract $0.25 \%$, Polypepton $0.5 \%$, $\mathrm{MgSO}_{4} \cdot 7 \mathrm{H}_{2} \mathrm{O} \quad 0.05 \%, \quad \mathrm{CaCl}_{2} \cdot 2 \mathrm{H}_{2} \mathrm{O} \quad 0.05 \%$, and $\mathrm{ZnSO}_{4} \cdot 7 \mathrm{H}_{2} \mathrm{O} 0.1 \%$ (pH 6.0).

Assay of the PDase Activity (Activity at 660 $\mathbf{m} \boldsymbol{\mu}) . \quad 0.2 \mathrm{ml}$ of $5 \%$ yeast RNA solution (purchased from N.B.C.) was added to a mixture of $1.0 \mathrm{ml}$ of $0.026 \mathrm{M}$ veronal acetate buffer $(\mathrm{pH}$ 6.0) and an appropriate amount of the enzyme solution. Water was added to the mixture up to the final volume, $2.0 \mathrm{ml}$. The reaction mixture was incubated at $60^{\circ} \mathrm{C}$ for 10 min., and then immersed into a boiling water for $5 \mathrm{~min}$. to stop the reaction. $0.5 \mathrm{ml}$ of the above was then incubated at $37^{\circ} \mathrm{C}$ for $2 \mathrm{hrs}$., with $0.5 \mathrm{ml}$ of snake ( $T$. flvoividis) venom $5^{\prime}$-nucleotidase obtained by Butler's method ${ }^{21}$ and $1.0 \mathrm{ml}$ of $0.05 \mathrm{M}$ Tris-HCl buffer ( $\mathrm{pH} 8.5$ ) containing $2 \times 10^{-3} \mathrm{M} \mathrm{MgCl}_{2}$. Inorganic phosphate was determined by the Allen's method, $22,0.5 \mathrm{ml}$ having been withdrawn from the above fuid thereafter. Thus, the difference of the amount of inorganic phosphate between the diesterasedigested solution and its $5^{\prime}$-nucleotidase-treated solution accounted for true inorganic phosphate liberated from 5'-mononucleotides produced by the PDase action upon the RNA. As was mentioned in the former paper, 19,20) $\mathrm{Zn}++$ was removed by Amberlite IR-120, prior to $5^{\prime}$-nucleotidase treatment in order to prevent $\mathrm{Zn}^{++}+$-inhibition of the enzyme activity, when the reaction mixture contained excess $\mathrm{Zn}^{+}+$.

Assay of RNase Activity by Determination of Ultraviolet Light Absorption in Acid-Soluble Materials (Activity at $260 \mathrm{~m} \boldsymbol{\mu}$ ). The same reaction mixture as above assay was incubated at $37^{\circ} \mathrm{C}$ for

19) Y. Hasegawa, T. Nakai, Y. Fujimura, Y. Kaneko and S. Doi, J. Agr. Chem. Soc. Japan, 38, 461 (1964).

20) Y. Fujimura, Y. Hasegawa, Y. Kaneko and S. Doi, ibid., 38, 467 (1964)

21) P. O. Hust and G. C. Butler, J. Biol. Chem., 193, 91 (I951).

22) R.J. L. Allen, Biochem. J., 34, 858 (1940). 
$30 \mathrm{~min}$. or at $60^{\circ} \mathrm{C}$ for $15 \mathrm{~min}$., and then chilled in an ice-water bath for $5 \mathrm{~min}$, to which $2.0 \mathrm{ml}$ of $0.25 \%$ uranium acetate- $2.5 \%$ perchloric acid reagent ${ }^{23)}$ was added. The mixture was kept at $0^{\circ} \mathrm{C}$ for $5 \mathrm{~min}$., centrifuged for $10 \mathrm{~min}$. at $800 \times \mathrm{g}$ and the supernatant was diluted 100 times with distilled water. Its optical density was measured at $260 \mathrm{~m} \mu$.

PDase Preparation. After cultivated in $100 \mathrm{ml}$ media of $500-\mathrm{ml}$ Sakaguchi flask on reciprocal shaker at $30^{\circ} \mathrm{C}, 7$ days, crude enzyme was obtained in the supernatant of the culture fluid, the cells having been centrifuged. Partially purified enzyme was prepared by the following procedure. Centrifuged supernatant was concentrated to about one fifth volume in vacuo at $40^{\circ} \mathrm{C}$, to which, at $-8^{\circ} \mathrm{C}$, cold acetone was slowly added in the cold room $\left(0 \sim 5^{\circ} \mathrm{C}\right)$ with gentle stirring until the concentration reached to $55 \%(\mathrm{v} / \mathrm{v})$. After being kept at $0^{\circ} \mathrm{C}$ for $30 \mathrm{~min}$., the brown precipitate formed (P-I) was centrifuged for $10 \mathrm{~min}$. at $10,000 \times \mathrm{g}$. Cold acetone was added to the supernatant until $80 \%$ $(\mathrm{v} / \mathrm{v})$ concentration was reached. After $30 \mathrm{~min}$. the precipitate (P-II) was obtained by centrifuging for $10 \mathrm{~min}$, at $10,000 \times \mathrm{g}$. The acetone concentration of supernatant was then raised up to $90 \%(\mathrm{v} / \mathrm{v})$ and the precipitate (P-III) was reformed. Only P-II fraction contained PDase activity.

CM-Cellulose Column Chromatography. CMCellulose column was prepared according to Peterson and Sober ${ }^{24}$ ) from Toyo Roshi cellulose powder (100 200 mesh). The column $(1.3 \times 28.5 \mathrm{~cm})$ was eqilibrated with $0.005 \mathrm{M}$ Acetate buffer ( $\mathrm{pH} 5.8$ ). The fraction $P$-II was dissolved into a small amount of $0.005 \mathrm{M}$ same buffer and dialyzed overnight against the same buffer. The dialyzate (O.D. at $280 \mathrm{~m} \mu$ : 69, O.D. at $660 \mathrm{~m} \mu: 200$ ) was applied on the top of the column and eluted at a rate of $20 \mathrm{ml}$ per $\mathrm{hr}$ with a concave gradient by $310 \mathrm{ml}$ of $0.005 \mathrm{M}$ Acetate buffer ( $\mathrm{pH} \mathrm{5.8)}$ in mixing vessel and $190 \mathrm{ml}$ of the same buffer of $0.5 \mathrm{M}$ in the reservoir. The fraction volume was $5 \mathrm{ml}$. Fig. 5 shows the pattern obtained.

Amberlite IRC-50 (XE-64) Column Chromatography. The above dialyzate (O.D. at $280 \mathrm{~m} \mu$ : 55.2, O.D. at $660 \mathrm{~m} \mu: 160$, O.D. at $260 \mathrm{~m} \mu: 13,2000$ ) was charged on to Amberlite XE-64. column $(1 \times 45$ $\mathrm{cm}$ ) previously bufferized with $0.005 \mathrm{M}$ acetate buffer (pH 5.8). The column was washed with the same

23) P. A. Mac. Fadyen, J. Biol. Chem., 107, 297 (1934).

24) E. A. Peterson and H. A. Sober, J. Am. Chem. Soc., 78, 751 (1955). buffer and then eluted with the same gradient system as used for CM-cellulose column chromatography at a rate of $40 \mathrm{mI}$ per hr. (Fig. 6). The fraction volume was $10 \mathrm{ml}$.

Activity towards bis-p-NPP of PDase. Reaction mixture $(3.0 \mathrm{ml})$ consisted of $1.0 \mathrm{ml}$ of $0.005 \mathrm{M} \mathrm{Na}$ bis- $p$-NPP, $1.0 \mathrm{ml}$ of $0.026 \mathrm{M}$ veronal acetate buffer $(\mathrm{pH} \mathrm{5.0)}$ or $0.01 \mathrm{M}$ Tris-HCl buffer ( $\mathrm{pH} 8.5$ ) and $1.0 \mathrm{ml}$ of the enzyme solution. The mixture, in which enzyme was replaced with water, was taken as blank. After incubation at $37^{\circ} \mathrm{C}$ for $2 \mathrm{hrs.}, 1.0 \mathrm{ml}$ of $1 \mathrm{~N}$ $\mathrm{NaOH}$ was added to the reaction. The amount of $p$-nitrophenol, which was liberated if the PDase cleaved the phosphate linkage of the substrate, was estimated by the O.D. at $430 \mathrm{~m} \mu$.

Paper Chromatography of RNA Digests by PDase. RNA digests by the crude and the partially purified PDase were spotted on Toyo Roshi No. 51 and developed either by $\mathrm{MeOH}$ (50)- $\mathrm{EtOH}$ (25)-conc. $\mathrm{HCl}(6)-\mathrm{H}_{2} \mathrm{O}(19)^{25)}$ or two dimensionally first by EtOH (75)-1 M CH $\mathrm{COONH}_{4}$, pH 7.5 (30), and then, by saturated $\left(\mathrm{NH}_{4}\right)_{2} \mathrm{SO}_{4}(80)-\mathrm{H}_{2} \mathrm{O}(2)$-isopropanol (18). ${ }^{26)}$ The U.V.-absorbing materials were detected as dark spots by Minera Light. 5'-Nucleotides were visible by the reaction of sugar moieties with Schiff's reagent after periodate oxidation. They were also demonstrated by detecting organic phosphate with HanesIsherwood's reagent.

Effect of $\mathrm{Zn}^{++}$on Dialyzed Enzyme. An appropriate amount of $\mathrm{ZnSO}_{4} \cdot 7 \mathrm{H}_{2} \mathrm{O} \quad\left(0 \sim 17 \times 10^{-4} \mathrm{M}\right.$, final concn.) was added to the PDase assay mixture containing $0.1 \mathrm{ml}$ of dialyzed enzyme.

\section{RESULTS}

\section{RNA Digestion by Crude PDase}

About $80 \%$ of RNA was hydrolyzed by the crude preparation of Pellicularia, basing upon the increase in inorganic phosphate liberated and in UV absorption in reaction mixture. The digest contained $5^{\prime}$-mononucleotides in 74, $\%$ equivalent amounts of RNA used. (Fig. 1).

Effect of $\mathrm{Zn}^{++}$on Dialyzate of Crude PDase

The culture fluid was dialyzed against distilled water for $24 \mathrm{hrs}$. $\left(\mathrm{H}_{2} \mathrm{O}\right.$-dialyzate).

25) K. S. Kirby, Biochim. Biophys. Acta, 18, 575 (1955).

26) F. Felix, J. L. Potter and M. Laskowski, $J$. Biol. Chem., 235, 1150 (1960). 


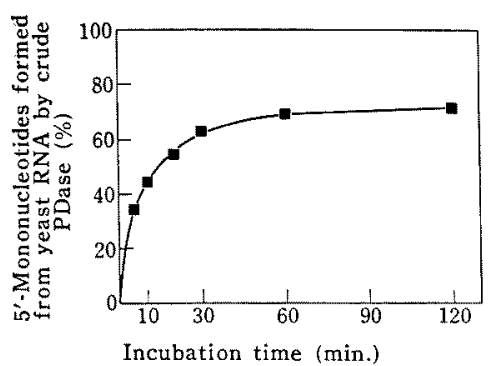

FIG. 1. Hydrolysis of RNA by PDase.

The reaction mixture, containing $0.2 \mathrm{ml}$ of $5 \%$ RNA, $1.0 \mathrm{ml}$ of veronal buffer $(\mathrm{pH} 6.0), 0.1 \mathrm{ml}$ of culture fluid and $0.7 \mathrm{ml}$ of $\mathrm{H}_{2} \mathrm{O}$, was incubated at $60^{\circ} \mathrm{C}$.

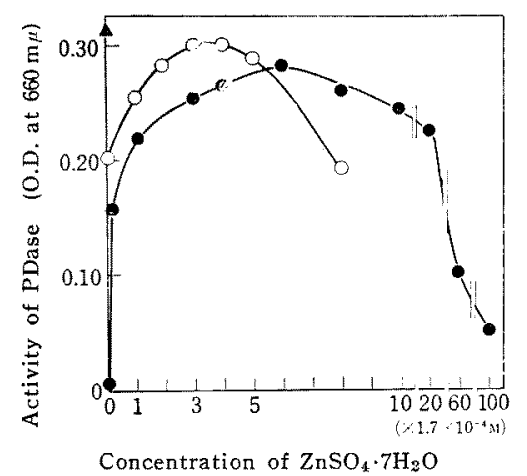

FIg. 2. Effect of $\mathrm{Zn}^{++}$on PDase of $\mathrm{H}_{2} \mathrm{O}$ - and EDTA-Dialyzate.

An appropriate amount of $\mathrm{ZnSO}_{4} \cdot 7 \mathrm{H}_{2} \mathrm{O}(0 \sim 1.7 \times$ $10^{-2} \mathrm{M}$ ) was added to the dialyzed PDase.

- :EDTA-dialyzate

$\mathrm{O}: \mathrm{H}_{2} \mathrm{O}$-dialyzate

A : Nondialyzed PDase

Also the culture fluid was dialyzed against $0.01 \mathrm{~m}$ EDTA for $24 \mathrm{hrs}$. and then against distilled water, which was frequently changed, for a week. (EDTA-dialyzate). When crude PDase was dialyzed against distilled water, the activity was partly lost, and, when against $0.01 \mathrm{~m}$ EDTA, it was completely inactivated. Both the partial and the complete inactivation could be perfectly recovered when a small amount of $\mathrm{Zn}^{++}$was added. The optimum $\mathrm{Zn}^{++}$concentration for recovery was $5.1 \times$
TABle I. EFFect of Metal IONS ON $\mathrm{H}_{2} \mathrm{O}$ DIALYZATE AND EDTA-DIALYZATE

Metal PDase Activity (O.D. at $660 \mathrm{~m} \mu$ )

$\begin{array}{lcc} & \mathrm{H}_{2} \mathrm{O}-\text { Dialyzate } & \text { EDTA-Dialyzate } \\ \text { None } & 0.210 & 0.010 \\ \mathrm{Ni}^{++} & 0.133 & 0.034 \\ \mathrm{Co}^{++} & 0.095 & 0.047 \\ \mathrm{Cu}^{++} & 0.100 & 0.010 \\ \mathrm{Ca}^{++} & 0.121 & 0.025 \\ \mathrm{Mg}^{++} & 0.274 & 0.002 \\ \mathrm{Mn}^{++} & 0.300 & 0.002 \\ \mathrm{Zn}^{++} & 0.258 & 0.210\end{array}$

Reaction mixture: $5 \%$ RNA, $0.2 \mathrm{ml}$; Veronal buffer, $\mathrm{pH} 6.0,1.6 \mathrm{ml}$; Metal ions, $0.1 \mathrm{ml}$, Final concn. $1.7 \times 10^{-4} \mathrm{M} ;$ Enzyme, $0.1 \mathrm{ml}$.

$10^{-4} \mathrm{M}$ in $\mathrm{H}_{2} \mathrm{O}$-dialyzate and $10.2 \times 10^{-4} \mathrm{M}$ in EDTA-dialyzate as shown in Fig. 2.

Effect of Several Metal Ions on $\mathrm{H}_{2} \mathrm{O}$ - and EDTADialyzate. As the influence of $\mathrm{Zn}^{++}$on the activity was found, the effects of other metal ions were examined on the dialyzate as described in Table I. The original activity of enzyme, O.D. 0.34 in $660 \mathrm{~m} \mu$, was inactivated down to 0.21 after $\mathrm{H}_{2} \mathrm{O}$-dialysis, but $\mathrm{Zn}^{++}, \mathrm{Mg}^{++}$ and $\mathrm{Mn}^{++}$restored its activity up to 0.26 , 0.27 and 0.30 , respectively. $\mathrm{Ni}^{++}, \mathrm{Co}^{++}$, $\mathrm{Ca}^{++}$and $\mathrm{Cu}^{++}$inhibited the activity of $\mathrm{H}_{2} \mathrm{O}-$ dialyzate, whereas the completely inactivated EDTA-dialyzed PDase was specifically recovered up to the original in $1.7 \times 10^{-4} \mathrm{M}$ by only $\mathrm{Zn}^{++}$

On the basis of above results, it might be speculated that PDase in culture fluid includes two kinds of metals, the one is easily removable by dialysis, i.e. $\mathrm{Mn}^{++}, \mathrm{Mg}^{++}$and $\mathrm{Zn}^{++}$as activator, and the other is the metal fraction at the active site which cannot be eliminated until treated by chelating agent like EDTA.

Comparison of PDase Activity (O.D. at $660 \mathrm{~m} \mu$ ) and RNase Activity (O.D. at $260 \mathrm{~m} \mu$ ) responding to pH changes. PDase activity and RNase activity were examined at $\mathrm{pH} 3$ through $\mathrm{pH} 9$ (Veronal buffer was used for $\mathrm{pH} 3$ through 6 and Tris buffer for $\mathrm{pH} 7$ through 9). The conditions of RNA hydrolysis were $60^{\circ} \mathrm{C}-15 \mathrm{~min}$ 


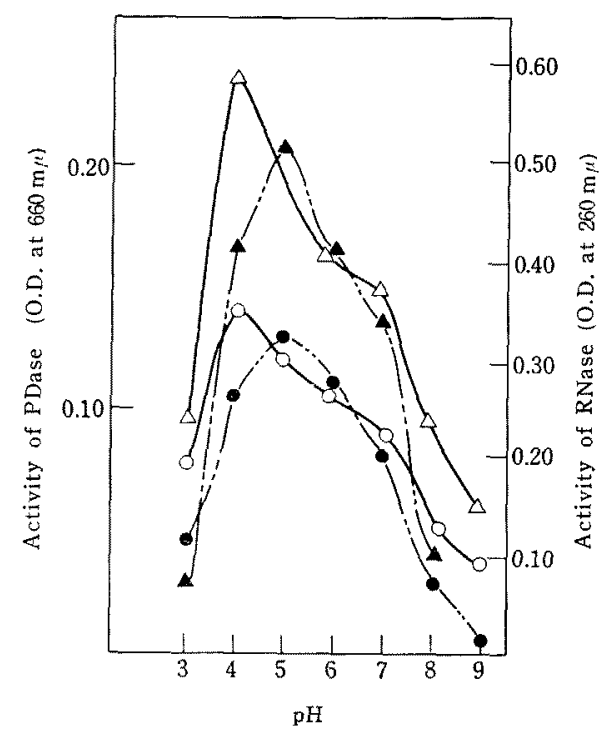

FIG. 3. Comparison of PDase Activity and RNase Activity at various $\mathrm{pH}$ values.

$$
\begin{aligned}
& \text { after }\left\{\begin{array}{l}
60^{\circ} \mathrm{C}-15 \mathrm{~min} . \text { reaction. } \\
37^{\circ} \mathrm{C}-30 \mathrm{~min} . \text { reaction. }
\end{array}\right. \\
& \text { after }\left\{\begin{array}{l}
60^{\circ} \mathrm{C}-15 \mathrm{~min} . \text { reaction. } \\
37^{\circ} \mathrm{C}-30 \mathrm{~min} .
\end{array}\right.
\end{aligned}
$$

and $37^{\circ} \mathrm{C}-30 \mathrm{~min}$. The optimal $\mathrm{pH}$ of PDase was 5.0, whereas that of RNase was 4.0 under both conditions (Fig. 3).

Furthermore, being shown in Table II, the fact was found that the degree in RNA hydrolysis and $5^{\prime}$-nucleotides formation exhibited discrepancy at every $\mathrm{pH}$, and that ratios of $5^{\prime}$-nucleotides formed per RNA hydrolyzed were not constant at each $\mathrm{pH}$.

More than half of RNA hydrolyzed was UV-absorbing materials besides $5^{\prime}$-mononucleotides during the comparatively early period of $60^{\circ} \mathrm{C}-15 \mathrm{~min}$. and $37^{\circ} \mathrm{C}-30 \mathrm{~min}$. reaction. After RNA digestion was sufficiently carried out at $60^{\circ} \mathrm{C}$ for 4 to $6 \mathrm{hr}$., $5^{\prime}$-mononucleotides occupied the most of RNA hydrolyzed (Fig. 1). These experiments indicate that the Pellicularia produces another RNase besides PDase.
TABLE II. RNA HYDROLYSIS AND 5'-NUCLEOTIDES FORMATION AT VARIOUS pH VALUES

$\begin{array}{cccc}\begin{array}{c}\mathrm{pH} \\ 60^{\circ} \mathrm{C},\end{array} & \begin{array}{c}\text { RNA } \\ \text { Hydrolyzed } \\ \% \text { (a)* }\end{array} & \begin{array}{c}5^{\prime}-\text { Nucleotides } \\ \text { Formed } \\ \%(\mathrm{~b})^{* *}\end{array} & (\mathrm{~b}) /(\mathrm{a}) \\ \text { Reaction } & & & \\ 3 & 37.5 & 5.3 & 0.141 \\ 4 & 75.0 & 26.6 & 0.354 \\ 5 & 65.2 & 32.0 & 0.490 \\ 6 & 56.5 & 26.6 & 0.471 \\ 7 & 52.1 & 20.3 & 0.389 \\ 8 & 37.5 & 7.3 & 0.194\end{array}$

$37^{\circ} \mathrm{C}$

$30 \mathrm{Min}$.

Reaction

$\begin{array}{rrrr}3 & 32.0 & 7.2 & 0.225 \\ 4 & 48.9 & 16.6 & 0.339 \\ 5 & 44.0 & 18.0 & 0.409 \\ 6 & 40.2 & 16.4 & 0.407 \\ 7 & 35.3 & 13.0 & 0.368 \\ 8 & 25.3 & 4.6 & 0.184 \\ 9 & 20.6 & 2.0 & 0.097\end{array}$

* Acid-soluble materials obtained from $\mathrm{KOH}$ hydrolysis of RNA was calculated as $100 \%$.

** Total Pi obtained from PCA hydrolysis of RNA was calculated as $100 \%$.

Paper Chromatography of RNA Digested by Crude or Partially Purified Preparations. RNA hydrolyzed by the crude and partially purified enzymes (tube number 55 and 56 of Fig. 6) at $60^{\circ} \mathrm{C}$ for $40 \mathrm{~min}$. (pH 5.0) was spotted on Toyo Roshi No. 51, and developed by ascending or descending solvent systems as shown in the Methods (Fig. 4). Both RNA hydrolyzates consisted mainly of four kinds of $5^{\prime}$-nucleotide. (AMP, GMP, CMP and UMP). At least three unknown spots and RNA core were shown on the chromatogram, which may be considered as nucleosides and oligonucleotides, respectively.

\section{Purification by Column Chromatography}

CM-Cellulose Column Chromatography. The acetone fraction, P-II, was chromatographed on CM-cellulose (Fig. 5). First peak was brown-colored impure proteins without activity. Second peak had PDase activity. Two PDase activities were found, which were activated by $\mathrm{Zn}^{++}$. 
(a)

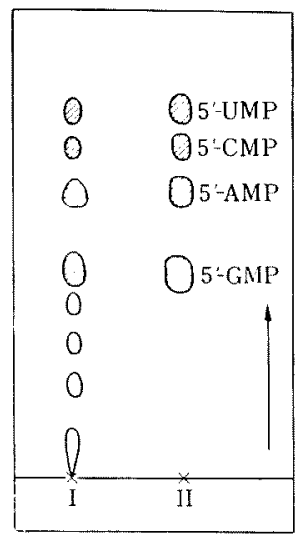

(b)

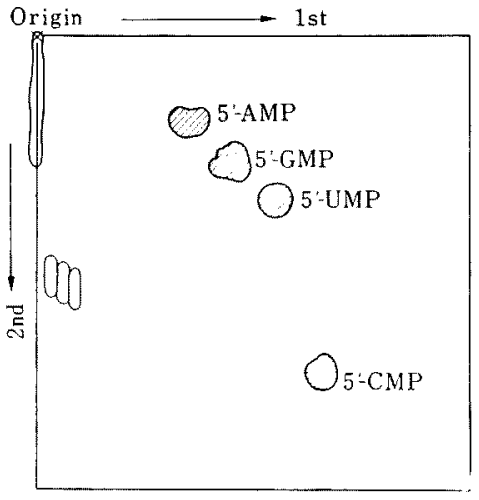

FIG. 4. Paper Chromatography of RNA Digested by Partially Purified Enzyme.

(a) One dimensional system, EtOH (50v/v)-MeOH(25)-Conc. $\mathrm{HCl}(6)-\mathrm{H}_{2} \mathrm{O}(19)$; I: Enzyme used was acetone P-II fraction or Amberlite XE-64 number 55 fraction; II. Standard.

(b) Two dimensional system, 1st: $\operatorname{EtOH}(75 \mathrm{v} / \mathrm{v})-1 \mathrm{M} \mathrm{CH} \mathrm{COONH}_{4}, \mathrm{pH} 7.5$ (30); 2nd: saturated $\left(\mathrm{NH}_{4}\right)_{2} \mathrm{SO}_{4}(80)-\mathrm{H}_{2} \mathrm{O}(2)$-isopropanol (18); Enzyme used was Amberlite XE-64 fraction number, 55 or 56 .

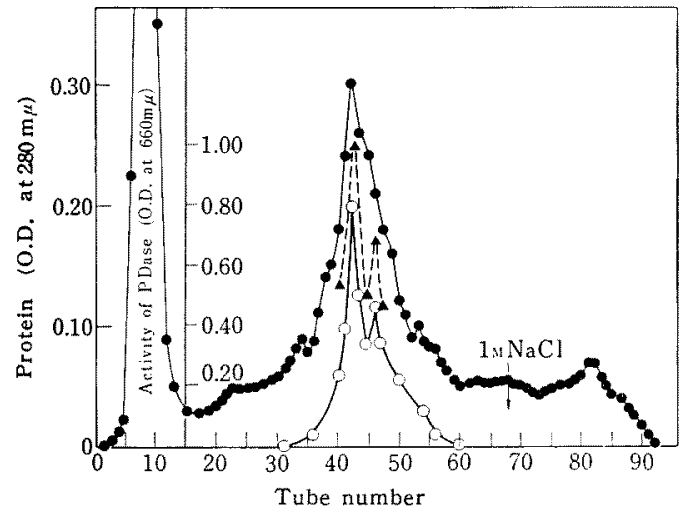

FIG. 5. Column Chromatography of Acetone P-II Fraction on CM-cellulose.

Total O.D. at $280 \mathrm{~m} \mu$ (- -69

Total O.D. at $660 \mathrm{~m} \mu$ (- $-\longrightarrow$ -, 200

O.D. at. $660 \mathrm{~m} \mu$ in $\mathrm{Zn}$ addition (-- - - )

Column size, $1.3 \mathrm{~cm} \times 28.5 \mathrm{~cm}$; Gradient elution with $0.005 \mathrm{M}$ Acetate buffer ( $\mathrm{pH} \mathrm{5.8)}$ and same buffer of $0.5 \mathrm{M}$.

Amberlite XE-64 Column Chromatography.

Several peaks were separated by Amberlite XE-64 column chromatography (Fig. 6). Two PDases (I, II) were separated into peaks III and $I V$, respectively. Maximal activity of
PDase I was in fraction number 53 and that of PDase II in fraction number 56.

When RNase activity was examined, it came in number 55 between two PDase peaks. Therefore, another kind of RNase might be also contained in this fraction, on which we refer later in discussion.

The specific activity of each step in purification was described in Table $V$. There was no loss in activity throughout the procedure of concentration. The acetone fractionation (P-II) increased specific activity of PDase by about five times of the initial, accompanying the yield of less than a half. Although CMcellulose did not display so much effect in purification procedure, in case of Amberlite XE-64 column chromatography, fraction number 55 was purified by 50 -fold in PDase activity and 120-fold in RNase activity. (Table III).

The yield of PDase in this chromatography was approximately one third of P-II fraction. It was probably due to loss of activator of PDase $\left(\mathrm{Zn}^{++}, \mathrm{Mg}^{++}\right.$and $\left.\mathrm{Mn}^{++}\right)$that PDase yield decreased through acetone treatment and column chromatography. As shown in 
Table IV, the addition of $\mathrm{Zn}^{++}$to the partially purified fraction, in fact, increased its

\section{Table III. PURIfication Procedure of Pellicularia PDASE}

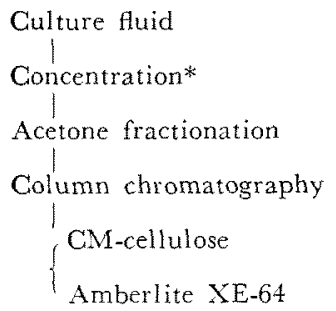

*Concentrated solution

Cold acetone $550^{\circ}\left(-8^{\circ} \mathrm{C}\right)$, kept standing for 30 min.

then centrifuged at $10,000 \times \mathrm{g}-10 \mathrm{~min}$.
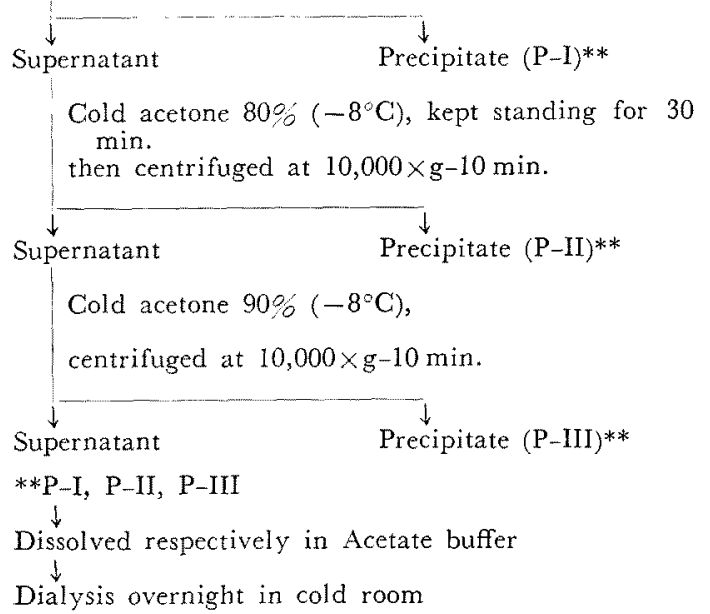

activity, and the addition of EDTA resulted in complete inactivation of number 53.

This indicates that PDase of Pellicularia contains metal-activator fraction easily removable by dialysis, acetone fractionation and column chromatography, besides, that it has $\mathrm{Zn}^{++}$-bound site, the metal of which cannot be taken away therefrom by such procedure except EDTA. Considering the above facts, the yield and specific activity of the purified preparation might be thought much higher, if, by adequate device, the metal deprival could be prevented.

$$
\begin{aligned}
& \text { TABLE IV. EFFECT OF } \mathrm{Zn}^{++} \text {AND EDTA }
\end{aligned}
$$

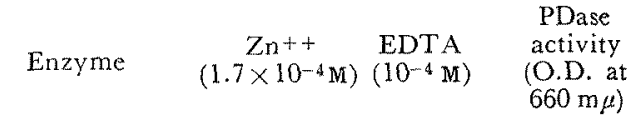

$$
\begin{aligned}
& \begin{array}{c}
\text { CM-cellulose } \\
\text { tube No. } 43
\end{array} \quad\left\{\begin{array}{lll}
1.0 & 0 & 0.235 \\
5.0 & 0 & 0.295
\end{array}\right. \\
& \begin{array}{lll}
10.0 & 5.0 & 0.225 \\
\text { Amberlite XE-64 } \\
\text { tube No. 53 }
\end{array}\left\{\begin{array}{lll}
0 & 0 & 0.155 \\
0.3 & 0 & 0.185 \\
0.7 & 0 & 0.252 \\
0 & 5.0 & 0 \\
1.0 & 5.0 & 0 \\
5.0 & 5.0 & 0.278 \\
10.0 & 5.0 & 0.304
\end{array}\right.
\end{aligned}
$$

Reaction mixture: $5 \%$ RNA, $0.2 \mathrm{ml} ; 0.143 \mathrm{M}$ Veronal buffer $(\mathrm{pH} \quad 5.0), 1.0 \mathrm{ml} ; \mathrm{Zn}^{++}, 0.1 \mathrm{ml}$; EDTA, $0.1 \mathrm{ml}$; Enzyme, $0.1 \mathrm{ml} ; \mathrm{H}_{2} \mathrm{O}, 0.5 \mathrm{ml}$.

\begin{tabular}{|c|c|c|c|c|c|c|}
\hline \multirow[b]{2}{*}{ Fractions } & & & \\
\hline & $\begin{array}{l}\text { Protein } \\
\text { O.D. at } \\
280 \mathrm{~m} \mu\end{array}$ & $\underset{\%}{\text { Yield }}$ & $\begin{array}{l}\text { PDase } \\
\text { O.D. at } \\
660 \mathrm{~m} \mu\end{array}$ & $\begin{array}{l}\text { Specific } \\
\text { activity }\end{array}$ & $\begin{array}{l}\text { RNase } \\
\text { O.D. at } \\
260 \mathrm{~m} \mu\end{array}$ & $\begin{array}{l}\text { Specific } \\
\text { activity }\end{array}$ \\
\hline Culture Fluid $(500 \mathrm{ml})$ & 1650 & 100 & 1000 & 1 & 180,000 & 1 \\
\hline Concentrated Soln. $(100 \mathrm{ml})$ & 1500 & 91 & 1050 & 1.1 & & \\
\hline Acetone P-II $(20 \mathrm{ml})$ & 138 & 9.2 & 400 & 4.7 & 33,000 & 2.2 \\
\hline \multicolumn{7}{|l|}{ Amberlite XE-64 } \\
\hline Tube No. 53 & 0.80 & & 9.0 & 18.4 & 23.5 & 10.8 \\
\hline 54 & 0.75 & & 1.5 & 3.3 & 65.0 & 32.1 \\
\hline 55 & 0.30 & & 10.1 & 55.8 & 100.0 & 122.5 \\
\hline 56 & 0.85 & & 19.9 & 38.6 & 33.0 & 13.5 \\
\hline 57 & 0.90 & & 5.7 & 10.3 & 12.0 & 4.9 \\
\hline
\end{tabular}

\section{Table V. Specific activity in PuRification Steps}




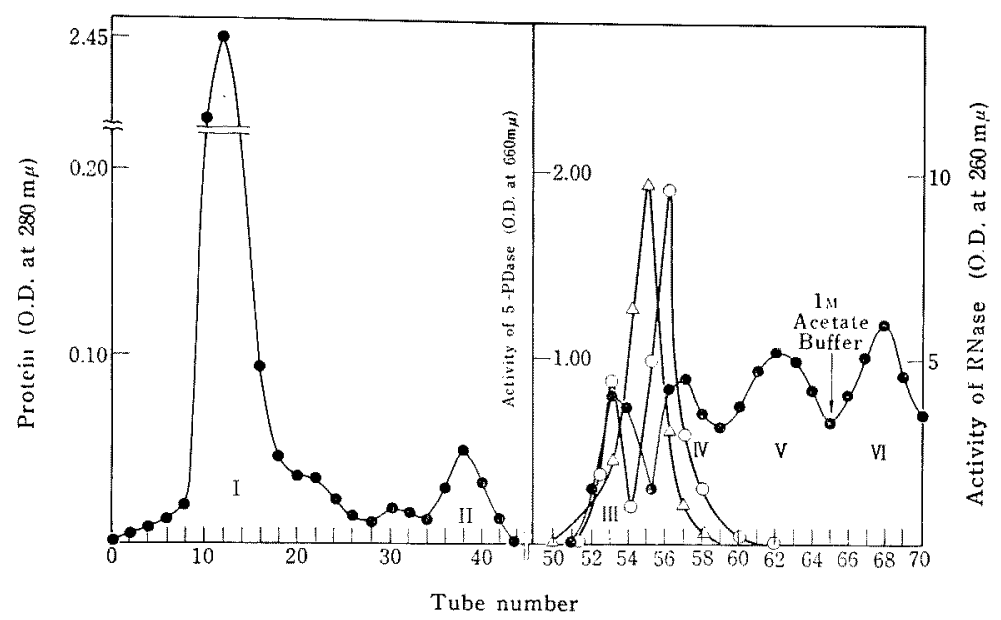

FIG. 6. Column Chromatography of Acetone P-II Fraction on Amberlite XE-64.

Total O.D. at $280 \mathrm{~m} \mu, 55.2$; Total O.D. at $260 \mathrm{~m} \mu, 13,200$; Total O.D. at $660 \mathrm{~m} \mu, 160$; $(-O-) \quad(-\Delta-)$ ( $-\mathrm{O}-)$

Column size, $1.0 \mathrm{~cm} \times 45.8 \mathrm{~cm}$; Gradient elution with $0.005 \mathrm{M}$ Acctate buffer and $0.5 \mathrm{M}$ Acetate buffer (pH 5.8).

\section{Comparison in Mode of the Action of Pelli-} zularia PDase and Snake Venom PDase towards bis-p-NPP. It was examined whether Pellicularia PDase attacked bis- $p-\mathrm{NPP}$, generally used as the synthetic substrate for PDase activity. The preparations were partially purified enzyme, acetone fraction (P-II) and Amberlite XE-64 chromatography fractions number 53, 55 and 56. The reaction condition was described in Methods. The pH 8.5 and 5.0 were applied as incubation $\mathrm{pH}$ for snake venom and Pellicularia PDase as indicated in Table VI.

Any Pellicularia preparations could never act on bis- $p$-NPP at both $\mathrm{pH}$ values, quite unlikely to RNA, whereas snake venom PDase hydrolyzed it considerably even in small amount. Therefore, it should be noted that PDase in Pellicularia, which exhibits no activity on bis$p$-NPP, is of different kind from snake venom enzyme and must be a new type PDase.

\section{DISCUSSION}

Pellicularia PDase is activated by $\mathrm{Zn}^{++}$and designated to $\mathrm{Zn}^{++}$-enzyme as described in
TABLE VI. Comparison OF THE ACtion OF Pellicularia PDASE AND SNAKE VENOM PDASE TOWARDS BIS- $p$-NPP

Enzyme

PDase Activity

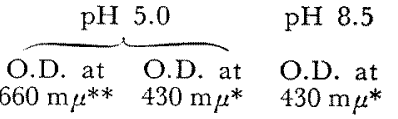

$\begin{array}{llll}\text { Snake Venom } & \text { Trace } & 0.110 & 0.650\end{array}$

Acetone fraction P-II $\quad 0.800 \quad 0.050 \quad 0.010$

Amberlite XE-64 fraction

$\begin{array}{rrrr}\text { No. } 53 & 0.900 & 0.015 & 0.010 \\ 55 & 1.110 & 0.020 & 0.007 \\ 56 & 1.990 & 0.015 & 0.005\end{array}$

* Reaction mixture: Bis-p-NPP, 5 mole, $1.0 \mathrm{ml}$; Enzyme, $1.0 \mathrm{ml} ; 37^{\circ} \mathrm{C}, 2 \mathrm{hr}$.

** Reaction mixture: $5 \%$ RNA, $0.2 \mathrm{ml} ; 0.143 \mathrm{~m}$ Veronal buffer ( $\mathrm{pH} 5.0$ ), $1.0 \mathrm{ml}$; Enzyme, $0.1 \mathrm{ml}$; $\mathrm{H}_{2} \mathrm{O}, 0.7 \mathrm{ml} ; 60^{\circ} \mathrm{C}, 10 \mathrm{~min}$.

Value of activity was calculated as $1.0 \mathrm{ml}$ of each fraction of Amberlite XE-64.

Results. There have been found several metal enzymes, for example, $\mathrm{Ca}^{++}$-binding $\alpha$ amylase, $\mathrm{Zn}^{++}$-binding alkaline phosphatase of 
E. coil found by Vallee and his co-workers ${ }^{2 n}$ and so on. There are until now few reports which show that PDase was activated by $\mathrm{Zn}^{++}$, and that PDase inactivated completely by EDTA was reversibly restored by only $\mathrm{Zn}^{++}$ among the metals so far tested.

In most cases it is accepted that $\mathrm{Zn}^{++}$is a potent inhibitor for PDase, i.e. for snake venom PDase. PDase in leukemic cells of mouse ${ }^{281}$ was accelerated by $\mathrm{Mg}^{++}$or $\mathrm{Mn}^{++}$. Of nucleases reported recently, calf pancreas PDase activity found by Terao and $\mathrm{Ukita}^{281}$ was dependent on $\mathrm{Co}^{++}$, that of $B$. subtilis ${ }^{21}$ on $\mathrm{Ca}^{++}$and that of $N$. $\operatorname{crassa}{ }^{9,10}$ on $\mathrm{Ca}^{++}$, $\mathrm{Mg}^{++}, \mathrm{Fe}^{++}$and $\mathrm{Na}^{+}$There have been found also $\mathrm{Mg}$-dependent potato nuclease $\mathrm{I}$ and micrococal nuclease. ${ }^{311}$ It could be assumed that Pellicularia PDase consists of activator and functional metal as shown in chart. The one was easily rernoved by $\mathrm{H}_{2} \mathrm{O}$-dialysis and reactivated by aliquot addition of $\mathrm{Mn}^{++}$, $\mathrm{Mg}^{++}$and $\mathrm{Zn}^{++}$, but the other retained its function until being captured by EDTA, chelating agent to seize the functional $\mathrm{Zn}^{++}$ $\mathrm{Zn}^{++}$addition reversibly recovered the enzyme activity lost completely by EDTA pretreatment.

It is interesting that the Pellicularia produces also other enzymes, which can be activated by $\mathrm{Zn}^{++}$like PDase, i.e. protease and $3^{\prime}$ nucleotidase. Two PDases were partially separated by Amberlite XE-64 chromato-

27) D. Plock, C. Levinthal and B. L. Vallee, Biochemistry, 1, 373 (1962).

28) E.P. Anderson and L. A. Heppel, Biochim. Biophys. Acta, 43, $79(1960)$

29) T. Terao and T. Ukita, Sym. on Enzyme Chemistry Japan (Tokyo), 16, 127 (1964).

30) W. Björk, Biochim. Biophys. Acta, 95, 652 (1965).

31) M. Landolt and M. P. deGarilhe, ibid., 91, $433(1964)$ graphy. Suzuki and Iwanaga ${ }^{32,331}$ demonstrated three PDases, PDase, I, II and III, from Japanese Mamushi venom.

Recently Lehman and Nussbaum ${ }^{11}$ and Kornberg et al. ${ }^{12,13)}$ proved the properties of exonuclease (PDase) I, II and III in $E$. coli. Also endonuclease I and II of $E$. coli ${ }^{34,35 !}$ and potato tubers ${ }^{301}$ were found.

At the end, substrate specificity of the enzyme should be discussed. Pellicularia PDase is thought to be incapable of splitting bis-pNPP. Leukemic cell PDase of mouse carrying ascites tumor, isolated by Anderson, ${ }^{28 !}$ as well as snake venom PDase hydrolyzes RNA, poly A, poly AU and oligonucleotides stepwise from terminal residue of the molecules. But the former cannot attack benzyladenosine $5^{\prime}$ phosphate or p-nitrophenyl thymidine 5 ' phosphate.

It was shown that a $\mathrm{Mn}^{++}$-dependent nuclease can digest RNA, RNase I core and DNA, but it cannot act on bis- $p$-NPP. ${ }^{36}$

Therefore, basing upon $\mathrm{Zn}^{++}$dependency and substrate specificity, Pellicularia PDase must be a new type nuclease.

In order to examine the specificities of RNase associated with PDase, much more purified preparations should be made.

Acknowledgement. The authers wish to express their sincere thanks to the researchers in the Department of Agricultural Chemistry, Nagoya University for their valuable discussion and warm help rendered to them through out this work.

32) T. Suzuki, S. Iwanaga and M. Satake, J. Pharm. Soc. Japan, 80, 861 (1960).

33) T. Suzuki and S. Iwanaga, ibid., 78, 362 (1958).

34) H. C. Neu and L. A. Heppel, Biochim. Biophys. Res. Comm., 17, 215 (1964).

35) P. F. Spahr, J. Biol. Chem., 239, 3716 (1964).

36) H. Sugimoto, T. Iwasa and T. Yokotsuka, J. Agr. Chem. Soc. Japan, 38, 135 (I964). 